\title{
Resource-Economic Growth Nexus, Role of Governance, Financial Development, Globalisation and War: Dynamic Approach
}

\author{
Professor Dr. Sorush Niknmian
}

\begin{abstract}
Ph.D. in Cell and Molecular Biology, CSci (Chartered Scientist), RSciTech (Registered Science Technician), RSci (Registered Scientist) ID: A0008833, Science Council, United Kingdom and Indiana Cancer Consortium (ICC) certified. Registered Researcher in the U.S. Government's System for Award Management. Registered Scientist at National Center for Biotechnology Information. Medical Student at Liberty University, United States of America, Military Medicine. BSc in Mechatronics Engineering and $\mathrm{BSc}$ in applied Mathematics.
\end{abstract}

\begin{abstract}
This study reassesses the resource-economic growth nexus by incorporating several channels. Advanced panel time series techniques are used to analyse panel time series data from 1980 to 2015 in 31 oil-rich countries. Results show that oil rent augments economic growth; thus, oil rent is conducive rather than impediment for economic growth. The role of governance in economic growth is significant in the selected countries. Oil rent exerts a positive significant impact on economic growth in countries with good governance compare to countries with poor governance. Financial development is an unimportant channel in the resource-growth nexus because FD is often unable to mobilise oil rent from the government to the private sector in oil-rich countries. Globalisation is advantageous for countries and promote economic growth. Moreover, war exerts a significant negative effect on growth in the long term.
\end{abstract}

Keywords: Resource; Economic Growth; Governance; War; Cross-Sectionally Augmented Distributed Lag (CSARDL)

\section{INTRODUCTION}

The relationship between resources and economic growth is intriguing and controversial. Literature on the resourcegrowth nexus can be divided into three strands. The first strand argues that resource abundance hinders economic growth through rent seeking and the Dutch disease process (Sachs and Warner, 1995, 1999, 2001; Gylfason, 2001; Mehlum et al., 2006). This argument has been criticised by researchers in the second strand of literature, which argues that the impact of natural resources on economic growth is conditional because it depends on the status of governance and other factors (Brunnschweiler, 2008; Van der Ploeg, 2011; Smith, 2015). The third strand of literature argues that resources benefit economic growth (Cavalcanti et al., 2011a, b).

The controversy about whether resource is a curse or a blessing motivated us to reassess the resource-growth nexus. An in-depth examination of existing literature showed that the variation in research findings is mainly due to the hypotheses adopted, variable selection, methodology and country selection. Many previous studies assessed the role of natural endowment in economic growth but disregarded several variables, such as financial development, globalisation and war. For instance, Van der Ploeg (2011) indicated that natural resource can be a curse or a blessing depending on several factors. The author added that developing countries with resource abundance are often incapable of efficiently transforming exhaustible resources into productive assets. This transformation requires a well-functioning financial market, but the mediating role of financial markets has not been sufficiently addressed in growth-resource literature (Sachs and Warner, 1995, 1999, 2001; Brunnschweiler, 2008; Cavalcanti et al., 2011a, b; Bhattacharyya and Hodler, 2010; Ebeke et al., 2015). 
Although Al-Mamun et al. (2017) resolved a few valid concerns, they overlooked an important variable, namely, the involvement of a country in war. Previous studies have indicated that the abundance of natural resources leads to conflicts or civil wars due to the misdistribution of the benefits of such resources (Collier and Hoeffler, 1998 \& 2004). Moreover, resource rent is often abused to finance wars (Collier and Hoeffler, 1998 \& 2004; Ross, 2004; Lujala et al., 2005). In this situation, a portion of government revenues is spent on war instead of being utilised for social development.

The interface between the resource-growth nexus and applied econometrics is often idealistic, with pragmatic justification for many studies founded on a feeble theoretical base. Several studies on the resource-growth nexus employed macro time series data and adopted a static econometric approach to analyse their model (e.g. Brunnschweiler, 2008; Smith, 2015). However, discovery of finite natural resources is characterised as an economic shock that persists for a long macroeconomic cycle, and a static approach fails to consider such an inter-temporal issue in its framework. Moreover, static analyses fail to capture the dynamism of resources in explaining growth. Hence, the validity of their findings is questionable. Apart from using appropriate econometric techniques, several prominent studies confined their scrutiny within a small frame due to the omission of important determinants that explain the resource-growth paradigm. As a result, the findings of these studies are merely speculative with regard to whether resource is a curse or a blessing to economic development. The concept of institution or governance is dynamic. The parameters that set the foundation of the concept of governance or quality of governance and the mechanism through which governance affects economic outcomes change rapidly. Exhaustive research is crucial for oil-rich countries to boost their economy by ensuring a sustainable pattern of growth. This study aims to provide policy recommendations.

This work contributes to the development of economics and governance literature in several ways. First, it overcomes several limitations of previous literature, such as econometric methods and variables. Second, it addresses crosssectional and endogeneity bias problems, which have not been considered in other studies. Lastly, the current work considers various mediating factors when explaining the resource-growth nexus.

The rest of the paper is structured as follows. Section 2 presents the hypothesis development and literature review. Section 3 introduces the data, descriptive statistics and methodology used in this study. Section 4 describes the main results on the resource-economic growth nexus in selected countries under various hypotheses, and Section 5 provides the conclusions.

\section{LITERATURE REVIEW AND HYPOTHESIS DEVELOPMENT}

\section{ECONOMIC GROWTH-RESOURCE NEXUS}

A number of empirical studies have assessed the impact of natural resources on economic growth, and each study has its own merits in improving our understanding of the natural resource-economic growth paradox. Existing literature can be classified into two strands.

The first strand argues that natural resources impede economic growth, and this relation is referred to as the resource curse paradox (e.g. Gelb, 1988; Auty, 1990; Sachs and Warner, 1995, 1999, 2001; Gylfason, 2001; Mehlum et al., 2006; Van der Ploeg, 2011; Kim and Lin, 2015). Sachs and Warner (2001) argued that countries with abundant natural resources experience sluggish economic growth compared with countries with minimal natural resources. Second strands argue Resource is important for modern economies where it is considered an indispensable factor for producing major goods and services. A number of studies have revealed that resource abundance amplifies economic growth (Alexeev and Conrad, 2009; Arezki and Van der Ploeg, 2007; Cavalcanti et al., 2011a, b; Smith, 2015; James, 2015). For instance, Cavalcanti et al. (2011a) reported that the negative association between resource and growth is a methodological choice.

The third strand of literature argues that natural resources can a blessing or a curse depending on the status of governance and other factors (Brunnschweiler, 2008; Van der Ploeg, 2011; Smith, 2015; Al-Mamun et al., 2017). Al-Mamun et al. (2017) argued that quality of governance is an important driver of economic growth in the longand short-term economies of oil-rich countries. This background enabled us to postulate our first hypothesis (H1). H1: Resource fosters economic growth in oil-rich countries. 


\section{ROLE OF QUALITY OF QOVERNANCE IN ECONOMIC GROWTH}

Although governance is the direct driver of economic growth according to neoclassical growth theories, studies have empirically proven that governance plays a mediating role in exerting economic growth. For example, standard neoclassical growth theories (Solow, 1956; Cass, 1965; Koopmans, 1963) argue that disproportionate factor accumulation, which is a direct product of various exogenous factors (e.g. saving rate (Solow, 1956), preferences (Cass-Koopmans, 1965), and technology (Romer, 1986) and physical and human capital accumulation (Romer, 1986; Lucas, 1988), is the primary cause of income equality among countries. Although theoretical models provide comprehensive insights into the growth paradigm, no reasonable answer has been established to explain the existence of high disparity in income level among countries. North and Thomas (1973) argued that the economic growth difference of countries should be ascribed to the discrepancy in institution or governance: the rules of the game in a society or, more formally, the humanly devised constraints that shape human interaction (North, 1990, p.3). Acemoglu et al. $(2001,2005)$ showed that the difference in institutions and quality of governance among countries can explain the differences in the economic performance of countries. Acemoglu and Robinson $(2008,2012)$ emphasised that the quality of political and economic institutions are vital factors that affect economic growth. Government accountability and being criticisable are promoted by high-quality governance that protects property rights, perfection of the market and incentives and innovation of the entrepreneur (North, 1990) and reduces the risk of expropriation and transaction costs (Butkiewicz and Yanikkaya, 2006). As a result, a proper political and economic environment can be established by governance, and its effect on making investment decisions is undeniable. Different indicators have been used to study the impact of governance on economic growth. For example, Knack and Keefer (1995) considered property rights and contract enforcement as governance indicators and statistically proved the significant positive impact of governance on economic growth. Similarly, Dollar and Kraay (2002) and Rigobon and Rodrik (2005) analysed the effect of the rule of law on economic growth and observed significant effects. This background enabled us to establish the following hypothesis.

$\mathrm{H} 2$ : Quality of governance fosters economic growth in oil-rich countries.

\section{ROLE OF GOVERNANCE IN ECONOMIC GROWTH-RESOURCE LINKAGE}

Previous studies have proven that the impact of resource on economic growth depends on the status of governance (Van der Ploeg, 2011; Brunnschweiler, 2008). Accruing the best potential outcome from natural endowment requires good governance to prevent rent seeking and a skewed distribution. Bhattacharyya and Hodler (2010) argued that corruption is increased by resource abundance in societies with poor democratic institutions. Corruption or poor governance diverts entrepreneurs from productive activities, which in turn impedes economic growth (Blackburn and Forgues-Puccio, 2009). Smith (2015) and Auty (1994) provided a similar notion that resource can be a curse or a blessing depending on the quality of governance. Thus, we formulate the following hypothesis.

H3: The impact of natural resources on economic growth is sensitive to the level of governance.

\section{ROLE OF FINANCIAL DEVELOPMENT IN ECONOMIC GROWTH-RESOURCE LINKAGE}

The possible role of financial development in economic growth in oil-rich countries can be further substantiated by the fact that these countries are often characterised by a narrow economic base that depends solely on highly depletable resources (Samargandi et al., 2015). Such a narrow economic base that reflects excessive natural resource possession is confirmed by the presence of low financial deepening (Bhattacharyya and Hodler, 2014). Financial development can play a vital role in redistributing the revenue from natural resources to the private sector (Demetriades and Hook Law, 2006). Financial market development also eliminates frictions in the market, which decreases transaction and information costs; eventually, symmetric information augments investment and economic growth (Goodhart, 2004). Given this notable role of financial development, a system with poor governance may obstruct the potential outcome of financial development in the process of market clearing and reducing information asymmetry (Al-Mamun et al., 2017). Despite its notable role, financial development has been overlooked by prior 
studies (Ross, 2001; Sachs and Warner, 1995; Mehlum et al., 2006). This scenario contextualises the joint effect of oil rent and financial development on explaining economic growth in oil-rich economies.

H4: The impact of oil rent is significant in the presence of high financial development.

\section{ROLE OF GLOBALISATION IN ECONOMIC GROWTH-RESOURCE LINKAGE}

With regard to the importance of economic globalisation, we further scrutinise the role of oil rent in enhancing economic growth by sampling the status of the economic globalisation index. Globalisation is the unification of goods and capital markets across the world by decreasing the barriers of international trade and foreign investment. Globalisation promotes the diffusion of technological progress by lowering transport costs, improving information flows across countries, reducing protectionism and liberalising foreign investment and migration rules. Improved integration positively affects economic growth (Alcala \& Ciccone, 2004; Frankel and Romer, 1999) and the quality of government (Al-Marhubi, 2004). Thus, an economy with a narrow base that depends on natural resources can be diversified by exploring new market opportunities through globalisation. Given the role of globalisation, we hypothesise that the role of oil rent is significant in countries with a high economic globalisation status.

H5: Oil rent is significant in countries with a high economic globalisation status.

\section{ROLE OF WAR IN ECONOMIC GROWTH-RESOURCE LINKAGE}

Previous studies have argued that abundance in natural resources leads to conflicts or civil wars due to the misdistribution of the resource benefit (Collier and Hoeffler, 1998 \& 2004). Similarly, Le Billon (2001) revealed that natural resources function as a motivational pretext of wars due to a skewed distribution of wealth across the world. Several studies argued that natural resources are often abused to finance wars (Collier and Hoeffler, 1998 \& 2004; Ross, 2004; Lujala et al., 2005). Pertaining to this thought, Collier and Hoeffler developed greed and grievance theories. Greed theory focuses on people who become rebellious to meet financial needs, and grievance theory focuses on arising ethnic and religious segregation, political oppression and discrimination. This study assumes that resource-based economies suffer from or undergo internal and external conflicts due to rebels and greedy outsiders, and these conflicts appear as substantial economic shocks. Such shocks are profound from the macroeconomic perspective because these economies respond seriously to resource revenue. Therefore, war is an important contextualisation in the resource-growth linkage. An anecdotal fact shows that the war in OPEC member countries exerts a significant impact on the international oil market, which influences the macroeconomic performance of oil importer and exporter countries. For example, the Iran-Iraq War from 1980-1989 shook the oil market and eventually led to a hike in oil prices in the international market. Therefore, the contextualisation of war occurrence is imperative in resource-growth investigations. We formulate following hypothesis.

H6: Growth-resource linkage is influenced through the channel of war negatively.

\section{DATA AND METHODOLOGHY}

\section{DATA}

Considering the role of institutions and war in the resource-economic growth linkage, this study investigated the growth-resource nexus by using panel data on 31 oil-rich countries1 obtained from 1980-2015. The logarithmic form of real gross domestic product (LGDPC) per capita was used as a dependent variable, similar to several studies (e.g. Cavalcanti et al., 2011a \& b; Apergis and Payne, 2014; Ebeke et al., 2015). Oil rent as a percentage of GDP was regarded as one of the independent variables. Governance quality (QOG) (known as institutional quality), which consists of corruption, law and order and bureaucracy quality indicators, was derived from the ICRG database

\footnotetext{
${ }^{1}$ Algeria, Argentina, Bahrain, Bolivia, Brunei, Cameroon, Canada, Colombia, Democratic Republic Congo, Egypt, Ecuador, Gabon, Indonesia, Iran, Iraq, Kuwait, Malaysia, Mexico, Nigeria, Norway, Oman, Qatar, Russia, Saudi Arabia, Syria, Trinidad and Tobago, Tunisia, United Arab Emirates, United Kingdom, United States and Venezuela.
} 
(Charron et al., 2010). The mean of the three indicators ranges from 0 to 1 . A score of 0 indicates the worst QOG, and 1 denotes the best QOG. QOG indicates neutral government institutions and implies that public officials do not grab anything from citizens/cases that is not stipulated prior to implementing any policy or law. The fourth hypothesis focuses on the role of financial development (FD) in the resource-economic growth linkage. Prior studies mentioned that financial development plays a major role in economic growth by enhancing resource allocation efficiency and productivity growth (Beck et al., 2000; Wurgler, 2000; Deidda, 2006; Beck, 2009) and that economic growth causes an increasing demand for credit to support financial development (Calderón and Liu, 2003; Ang, 2008; Yang and Yi, 2008; Rufael, 2009; Fowowe, 2010; Zhang et al., 2012; Raz, 2013). Thus, this study uses the financial development (FD) index comprising credit to the private sector and money supply. The other control variables used in this study were general government final consumption expenditure (\% of GDP) (GOV), gross fixed capital formation (\% of GDP) (FCF) and population growth (POPG).

\section{METHODOLOGY}

Standard panel unit-root approaches assume that each series is cross-sectional independent, and no spill-over effect occurs among cross countries. In practice, cross-sectional dependency arises due to trade, common financial integration and other unobserved factors (Hsiao, 2003; Pesaran and Tosetti, 2011). Thus, considering cross-section dependency in a panel unit-root test is important in selecting an appropriate technique for model estimation. We employed the cross-sectional dependence (CD) test suggested by Pesaran (2004) to investigate interdependence and the correlation coefficient. The null hypothesis of the $\mathrm{CD}$ test is cross-sectional independence, and the alternative hypothesis is the presence of cross-sectional dependence among units.

$$
C D=\sqrt{2 T / N(N-1)}\left(\sum_{i=1}^{N-1} \sum_{j=i+1}^{N} \hat{\rho}_{i j}\right) \text {, }
$$

Where $\hat{\rho}_{i j}=\hat{\rho}_{j i}=\frac{\sum_{t=1}^{T} e_{i t} e_{j t}}{\left(\sum_{t=1}^{T} e_{i t}^{2}\right)^{1 / 2}\left(\sum_{t=1}^{T} e_{j t}^{2}\right)^{1 / 2}}, e_{i t}$ indicates the residuals that originate from the adopted regression and $y_{i t}=\alpha_{i}+\beta_{i} x_{i t}+u_{i t}$. In this regression, $x_{i t}$ denotes a vector $k \times 1$ dimension of independent variables and can include lags of the dependent variable. $y_{i t}$ is the dependent variable for i countries at time $\mathrm{t}$. $\mathrm{T}$ and $\mathrm{N}$ denote cross section and time dimension, respectively?

In the presence of a CD problem, any standard panel technique, such as Levin, Lin and Chu's (LLC) Im and Pesaran and Shin's IPS, may provide misleading outcomes. To address this problem, Pesaran (2007) introduced the crosssection dependence test by combining two unit-root tests, namely, ADF and IPS, and considering cross-sectional dependence. To estimate the CIPS statistic, an augmented Dickey-Fuller regression is required.

$$
\Delta \mathrm{y}_{i t}=\alpha_{i}+k_{i} \mathrm{t}+\beta_{i} y_{i t-1}+\gamma_{i} \bar{y}_{t-1}+\emptyset_{i} \Delta \bar{y}_{t}+\varepsilon_{i t}+\cdots,
$$

where $\bar{y}_{t}$ shows the mean of $\mathrm{y}_{i t}$ for each unit. To investigate stationary variables while considering cross-sectional dependence, the null and alternative hypotheses are $H_{0}: \beta_{i}=0$ and $H_{1}: \beta_{i}<0$, respectively. The CIPS statistics is

$$
\operatorname{CIPS}(\mathrm{N}, \mathrm{T})=\frac{1}{\mathrm{~N}} \sum_{\mathrm{i}=1}^{\mathrm{N}} \tau_{\mathrm{i}}(\mathrm{N}, \mathrm{T}) \text {, }
$$

Notably, $\tau_{\mathrm{i}}(\mathrm{N}, \mathrm{T})$ denotes the $\mathrm{t}$ statistic of $\beta_{i}$.

To select an appropriate framework to estimate models and obtain robust findings, we applied a number of techniques that can capture heterogeneity, cross-sectional dependence or both. Heterogeneity is an important issue to consider due to its potential country-specific effect. Several methods, such as mean group OLS (MG) (Pesaran and Smith, 1995), pooled mean group (PMG) (Pesaran et al., 1999), panel fully modified OLS (Pedroni, 2000) and panel dynamic OLS (Pedroni, 2001), have been introduced to solve the heterogeneity problem in panel time series data. However, these techniques are inconsistent when a cross-sectional dependence problem exists (Neal, 2015). To address the CD bias problem, new advanced techniques, such as common correlated effects (CCE) (Pesaran, 2006), common correlated effects pooled (CCEP), common correlated effects mean group (CCEMG) and augmented mean group (AMG) (Bond and Eberhardt, 2013), have been introduced. Nevertheless, these techniques are consistent only for the static nature of panel-time series data with strict heterogeneity. Therefore, other methods, such as CS-ARDL, have been established. Chudik and Pesaran (2015) developed the cross-section autoregressive distributed lag (CSARDL) method for dynamic panels and solved the aforementioned problems. The equation is

$$
y_{i, t}=\alpha_{i}+\lambda_{i} y_{i, t-1}+\beta_{i} x_{i, t}+u_{i, t} \text {, }
$$


where $u_{i, t}$ comprises idiosyncratic error terms assumed to be cross sectionally and weakly dependent. In addition, the lagged dependent variable is not strictly exogenous; thus, the estimator is inconsistent. To achieve a consistent estimator, $\sqrt[3]{T}$ lags of the cross section means are added to Equation (4). The following equation is then derived.

$$
y_{i, t}=\alpha_{i}+\lambda_{i} y_{i, t-1}+\beta_{i} x_{i, t}+\sum_{l=0}^{P T} \dot{\delta}_{i, l} \bar{z}_{t-l}+e_{i, t}
$$

The number of lags is defined by optimum lag selection criteria (PT) and $\bar{z}_{t}=\left(\bar{y}_{t-1}, \bar{x}_{t}\right)$ in Equation (5). Owing to $\lambda_{i}$ and $\beta_{i}, \pi_{i}=\left(\lambda_{i}, \beta_{i}\right)$ can be written, where $\alpha_{i}$ country is a specific intercept and $\lambda_{i}$ is the coefficient of the lag of the dependent variable. The equation further shows $\delta_{i, l}$ is the coefficient of the autoregressive part, and $\bar{z}_{t}$ is the set of mean dependent and independent variables. The mean group estimator in Equation (6) is following

$$
\hat{\pi}_{M G}=\frac{1}{N} \sum_{i=1}^{N} \hat{\pi}_{i}
$$

In several conditions, such as $(N, T, P T) \Rightarrow \infty$ and full ranking of factor loadings, $\hat{\pi}_{i}$ and $\hat{\pi}_{M G}$ are consistent (Chudik and Pesaran, 2015).

The pooled mean group estimator considers long-term homogeneity, whereas the short-term heterogeneous effect of the independent variable is on the dependent variable. Thus, Equation (1) is rewritten as an error correction model as follows:

$$
\Delta y_{i, t}=\phi_{i}\left(y_{i, t-1}\right)+\theta_{1, i} x_{i, t}+\delta_{0, i}+\delta_{1, i} \Delta x_{i, t}+\epsilon_{i, t}
$$

where $\phi_{i}$ is the error-correction speed and $\theta$ and $\delta$ denote long- and short-term coefficients, respectively. The mean group estimator in the short term is

$$
\hat{\delta}_{M G}=\frac{1}{N} \sum_{i=1}^{N} \hat{\delta}_{i} \text {. }
$$

The MG and PMG estimators are consistent under large $\mathrm{N}$ and $\mathrm{T}$ conditions, and a bias problem may occur in a small sample in dynamic heterogeneous panels. Therefore, Chudik and Pesaran (2015) utilised the 'half-panel' jack knife and recursive mean adjustment to address the bias problem. The mean group estimator of the jack knife and the recursive mean adjustment are

$$
\begin{aligned}
& \tilde{\pi}_{M G}=2 \hat{\pi}_{M G}-\frac{1}{2}\left(\hat{\pi}_{M G}^{a}+\hat{\pi}_{M G}^{b}\right), \\
& \widetilde{\omega}_{i t}=\omega_{i t}-\frac{1}{t-1} \sum_{s=1}^{t-1} \omega_{i s},
\end{aligned}
$$

where $\omega_{i t}=\left(y_{i t}, x_{i t}\right)$ and $\hat{\pi}_{M G}^{a}$ and $\hat{\pi}_{M G}^{b}$ denote the mean group estimate of the first and second half of the sample, respectively.

We estimated these models through the DCCE method.

$\Delta \operatorname{lnGDPC}_{\mathrm{i}, \mathrm{t}}=\delta_{\mathrm{i}}+\varphi_{\mathrm{i}}\left(\operatorname{lnGDPC}_{\mathrm{i}, \mathrm{t}-1}\right)+\theta_{1} \mathrm{FCF}_{\mathrm{i}, \mathrm{t}}+\theta_{2} \mathrm{GOV}_{\mathrm{i}, \mathrm{t}}+\theta_{3} \mathrm{PG}_{\mathrm{i}, \mathrm{t}}+\theta_{4} \mathrm{OILRENT}_{i, t}$

$$
\begin{aligned}
& +\sum_{\mathrm{j}=0}^{\mathrm{q}-1} \delta_{1 \mathrm{j}}{ }_{\mathrm{i}}^{\mathrm{i}} \Delta \mathrm{FCF}_{\mathrm{i}, \mathrm{t}-\mathrm{j}}+\sum_{\mathrm{j}=0}^{\mathrm{q}-1} \delta_{2 \mathrm{j}}{ }^{\mathrm{i}} \Delta \mathrm{GOV}_{\mathrm{i}, \mathrm{t}-\mathrm{j}}+\sum_{\mathrm{j}=0}^{\mathrm{q}-1} \delta_{3 j}{ }_{\mathrm{j}}^{\mathrm{i}} \Delta \mathrm{PG}_{\mathrm{i}, t-\mathrm{j}} \\
& +\sum_{\mathrm{j}=0}^{\mathrm{q}-1} \delta_{4}{ }_{\mathrm{j}}^{\mathrm{i}} \Delta \text { OILRENT }_{\mathrm{i}, \mathrm{t}-\mathrm{j}}+\sum_{\mathrm{l}=0}^{P T} \delta_{\mathrm{i}, \mathrm{l}} \overline{\mathrm{Z}}_{t-l}+\varepsilon_{\mathrm{i}, \mathrm{t}}
\end{aligned}
$$

$$
\begin{aligned}
& \Delta \operatorname{lnGDPC}_{\mathrm{i}, \mathrm{t}}=\delta_{\mathrm{i}}+\varphi_{\mathrm{i}}\left(\operatorname{lnGDPC}_{\mathrm{i}, \mathrm{t}-1}\right)+\theta_{1} \mathrm{FCF}_{\mathrm{i}, \mathrm{t}}+\theta_{2} \mathrm{GOV}_{\mathrm{i}, \mathrm{t}}+\theta_{3} \mathrm{PG}_{\mathrm{i}, \mathrm{t}}+\theta_{4} \mathrm{OILRENT}_{i, t}+\theta_{5} \mathrm{QOG}_{i, t} \\
& +\sum_{\mathrm{j}=0}^{\mathrm{q}-1} \delta_{1 \mathrm{j}}^{\mathrm{i}} \Delta \mathrm{FCF}_{\mathrm{i}, \mathrm{t}-\mathrm{j}}+\sum_{\mathrm{j}=0}^{\mathrm{q}-1} \delta_{2 \mathrm{j}}^{\mathrm{i}} \Delta \mathrm{GOV}_{\mathrm{i}, \mathrm{t}-\mathrm{j}}+\sum_{\mathrm{j}=0}^{\mathrm{q}-1} \delta_{3 \mathrm{j}}{ }^{\mathrm{i}} \Delta \mathrm{PG}_{\mathrm{i}, \mathrm{t}-\mathrm{j}} \\
& +\sum_{\mathrm{j}=0}^{\mathrm{q}-1} \delta_{4 \mathrm{j}}{ }_{\mathrm{j}}^{\mathrm{i}} \Delta \operatorname{OILRENT}_{\mathrm{i}, \mathrm{t}-\mathrm{j}}+\sum_{\mathrm{j}=0}^{\mathrm{q}-1} \delta_{5}{ }_{\mathrm{j}}^{\mathrm{i}} \Delta \mathrm{QOG}_{\mathrm{i}, \mathrm{t}-\mathrm{j}}+\sum_{\mathrm{l}=0}^{P T} \delta_{\mathrm{i}, 1}{ }^{\prime} \bar{Z}_{t-l}+\varepsilon_{\mathrm{i}, \mathrm{t}} \\
& \Delta \operatorname{lnGDPC}_{\mathrm{i}, \mathrm{t}}=\delta_{\mathrm{i}}+\varphi_{\mathrm{i}}\left(\operatorname{lnGDPC}_{\mathrm{i}, \mathrm{t}-1}\right)+\theta_{1} \mathrm{FCF}_{\mathrm{i}, \mathrm{t}}+\theta_{2} \mathrm{GOV}_{\mathrm{i}, \mathrm{t}}+\theta_{3} \mathrm{PG}_{\mathrm{i}, \mathrm{t}}+\theta_{4} \mathrm{OILRENT}_{i, t}+\theta_{5} \mathrm{QOG}_{i, t} \\
& +\theta_{6}\left(\operatorname{OILRENT}^{*} \mathrm{QOG}\right)_{i, t}+\sum_{\mathrm{j}=0}^{\mathrm{q}-1} \delta_{1 \mathrm{j}}^{\mathrm{i}} \Delta \mathrm{FCF}_{\mathrm{i}, \mathrm{t}-\mathrm{j}}+\sum_{\mathrm{j}=0}^{\mathrm{q}-1} \delta_{2 \mathrm{j}}{ }_{\mathrm{j}}^{\mathrm{i}} \Delta \mathrm{GOV}_{\mathrm{i}, \mathrm{t}-\mathrm{j}} \\
& +\sum_{\mathrm{j}=0}^{\mathrm{q}-1} \delta_{3 j}{ }_{\mathrm{j}}^{\mathrm{i}} \Delta \mathrm{PG}_{\mathrm{i}, t-\mathrm{j}}+\sum_{\mathrm{j}=0}^{\mathrm{q}-1} \delta_{4 \mathrm{j}}{ }^{\mathrm{i}} \Delta \operatorname{OILRENT}_{\mathrm{i}, \mathrm{t}-\mathrm{j}}+\sum_{\mathrm{j}=0}^{\mathrm{q}-1} \delta_{5}{ }_{5}^{\mathrm{i}} \Delta \mathrm{QOG}_{\mathrm{i}, t-\mathrm{j}} \\
& +\sum_{\mathrm{j}=0}^{\mathrm{q}-1} \delta_{6}{ }_{\mathrm{j}}^{\mathrm{i}} \Delta\left(\text { OILRENT }^{*} \mathrm{QOG}\right)_{\mathrm{i}, t-\mathrm{j}}+\sum_{\mathrm{l}=0}^{P T} \delta_{\mathrm{i}, 1} \overline{\mathrm{Z}}_{t-l}+\varepsilon_{\mathrm{i}, \mathrm{t}}
\end{aligned}
$$




$$
\begin{aligned}
& \Delta \operatorname{lnGDPC}_{\mathrm{i}, \mathrm{t}}=\delta_{\mathrm{i}}+\varphi_{\mathrm{i}}\left(\operatorname{lnGDPC}_{\mathrm{i}, \mathrm{t}-1}\right)+\theta_{1} \mathrm{FCF}_{\mathrm{i}, \mathrm{t}}+\theta_{2} \mathrm{GOV}_{\mathrm{i}, \mathrm{t}}+\theta_{3} \mathrm{PG}_{\mathrm{i}, \mathrm{t}}+\theta_{4} \mathrm{OILRENT}_{i, t}+\theta_{5} \mathrm{~F}_{i, t} \\
& +\theta_{6}\left(\text { OILRENT }^{*} \mathrm{FD}\right)_{i, t}+\sum_{\mathrm{j}=0}^{\mathrm{q}-1} \delta_{1 \mathrm{j}}{ }^{\mathrm{i}} \Delta \mathrm{FCF}_{\mathrm{i}, \mathrm{t}-\mathrm{j}}+\sum_{\mathrm{j}=0}^{\mathrm{q}-1} \delta_{2 \mathrm{j}}{ }_{\mathrm{i}}^{\mathrm{i}} \Delta \mathrm{GOV}_{\mathrm{i}, \mathrm{t}-\mathrm{j}} \\
& +\sum_{\mathrm{j}=0}^{\mathrm{q}-1} \delta_{3 \mathrm{j}}{ }_{\mathrm{i}}^{\mathrm{i}} \Delta \mathrm{PG}_{\mathrm{i}, \mathrm{t}-\mathrm{j}}+\sum_{\mathrm{j}=0}^{\mathrm{q}-1} \delta_{4{ }_{\mathrm{j}}}{ }_{\mathrm{i}} \Delta \operatorname{OILRENT}_{\mathrm{i}, t-\mathrm{j}}+\sum_{\mathrm{j}=0}^{\mathrm{q}-1} \delta_{5}{ }_{\mathrm{j}}^{\mathrm{i}} \Delta \mathrm{FD}_{\mathrm{i}, \mathrm{t}-\mathrm{j}} \\
& +\sum_{\mathrm{j}=0}^{\mathrm{q}-1} \delta_{6}{ }_{\mathrm{j}}^{\mathrm{i}} \Delta\left(\text { OILRENT }^{*} \mathrm{FD}\right)_{\mathrm{i}, \mathrm{t}-\mathrm{j}}+\sum_{\mathrm{l}=0}^{P T} \delta_{\mathrm{i}, \mathrm{l}}^{\prime} \overline{\mathrm{Z}}_{t-l}+\varepsilon_{\mathrm{i}, \mathrm{t}}
\end{aligned}
$$

\section{RESULTS AND DISCUSSIONS}

\section{CROSS-SECTIONAL DEPENDENCY AND ORDER OF INTEGRATION}

We apply the CD test developed by Pesaran (2004) to investigate the contemporaneous correlation across the 31 countries. The test is based on the average of the pair-wise correlations of OLS residuals from the individual regressions in the panel. The null hypothesis of the $\mathrm{CD}$ test is cross-sectional independence, and the alternative hypothesis is the presence of CD among the selected countries. The result of the CD test (Table 1) showed that each series in the panel exhibited cross-sectional dependence. Therefore, the CIPS ( $Z$ 't-bar') test for unit roots by Pesaran (2007) was applied. This unit root test allows for cross-sectional dependence. These tests were conducted with a constant term at the level and in the first difference. The fourth and fifth columns of Table 1 present the CIPS ( $\mathrm{Z}$ ' $\mathrm{t}$ bar') statistic for level and the first difference forms of the variable, respectively. Every series was stationary at the level form, except for LGDPC and FD. Table 1 shows that all variables were stationary after the first difference.

Table 1: Cross-sectional dependency test and panel unit-root test

\begin{tabular}{lllll}
\hline \multicolumn{2}{l}{ Cross Sectional Dependency Test } & & & \multicolumn{1}{c}{ Panel Unit-Root Test } \\
\hline Variables & CD Test & $\rho$ & CIPS (Level) & CIPS (1st Difference) \\
\hline LGDPC & $32.82^{* * *}$ & 0.593 & -0.482 & $-7.522^{* * *}$ \\
GOV & $7.71^{* * * *}$ & 0.349 & $-2.959^{* * *}$ & $-12.210^{* * * *}$ \\
FCF & $12.86^{* * *}$ & 0.312 & $-3.355^{* * *}$ & $-12.436^{* * * *}$ \\
OIL RENT & $52.83^{* * *}$ & 0.470 & $-3.227^{* * *}$ & $-15.518^{* * * *}$ \\
POPG & $28.43^{* * *}$ & 0.508 & $-9.194^{* * *}$ & $-16.034^{* * *}$ \\
FD & $20.08^{* * *}$ & 0.477 & 0.055 & $-9.791^{* * *}$ \\
QOG & $11.79^{* * *}$ & 0.453 & $-2.400^{* * *}$ & $-10.532^{* * * *}$ \\
GLOBALISATION & $108.39^{* * *}$ & 0.838 & $-2.033^{*}$ & $-4.015^{* * *}$ \\
\hline
\end{tabular}

Note: $* * *, * *$ and $*$ indicate the level of significance at $1 \%, 5 \%$, and $10 \%$, respectively.

\section{HYPOTHESES}




\subsection{RESOURCE, GOVERNANCE AND ECONOMIC GROWTH NEXUS}

Our first hypothesis involves determining whether natural resources, particularly oil, are positively or negatively associated with growth. Table 2 shows that the existence of a long-run causality from all explanatory variables to economic growth is confirmed by negative and of error correction coefficient. The findings from the main model report that oil rent was positively and significantly associated with economic growth. This finding coincides with that of several prominent studies that documented that resource abundance amplifies economic growth (Alexeev and Conrad, 2009; Arezki and Van der Ploeg, 2007; Cavalcanti et al., 2011a, b; Smith, 2015; James, 2015). For example, Cavalcanti et al. (2011a) refuted the claim that oil abundance negatively affects economic growth and posed a challenge to others after obtaining a positive association between natural resources and economic growth in their empirical research. The studies conducted by Alexeev and Conrad (2009), Arezki and Van der Ploeg (2007), Cavalcanti et al. (2011b) and Van der Ploeg and Poelhekke (2010) questioned the validity of the resource curse paradox of Sachs and Warner $(1995,1999,2001)$ and found that oil revenue windfalls do not cause economic growth. Using the negative but insignificant coefficient of oil rent in the short term to indicate whether an economy benefits from oil rent is inconclusive.

Our second hypothesis is that quality of governance fosters economic growth. The coefficient of quality of governance is positive and significant in the long. In-depth examination of the coefficients suggested that quality of governance is the most important determinant of economic growth for the sample countries in the short and long terms. The estimated coefficient suggests that a unit increase in the quality of governance would lead to approximately 0.771 unit increase in economic growth in the selected countries in the long. Our result is consistent with those of previous studies, such as Demetriades and Hook Law (2006), for different countries, except for the least-developed ones. However, the findings of Demetriades and Hook Law (2006) will not apply if we correct the cross-sectional bias for their sample countries. Therefore, our finding is robust and superior to the conclusions of Demetriades and Hook Law (2006). The main results presented in Table 2 provide evidence that quality of governance is important for economic growth in oil-rich economies. Given that the majority of oil-rich countries in the world are members of OPEC, our empirical findings on the positive role of quality of governance are expected. The third hypothesis in this work is that oil rent combined with governance significantly affects economic growth. This hypothesis is confirmed because the coefficient of oil rent and governance interaction is positive and significant for long term. Thus, we established the main link between oil rent and economic growth in oil-rich countries by clustering the sample into high and low governance. Table 2 shows that the coefficient of oil rent was positive and significant in the long term in the case of low-governance and high-governance countries. Our finding coincides with the argument that the relation between resource and economic growth is manifested through governance status (Van der Ploeg, 2011; Brunnschweiler, 2008). Van der Ploeg (2011) added that natural resources can be a 'curse' or a 'blessing' depending on various factors, such as rent seeking and violence, institutional quality and financial systems. Several other studies argued that poor institutional quality is the outcome of natural resources because dependence on natural resources leads to market and institutional failures that incur sluggish economic growth (Auty, 1994; Bhattacharyya and Hodler, 2010; Gylfason, 2001; Sachs and Warner, 1995).

Table 2: Growth, resource and governance

\begin{tabular}{llllll}
\hline \multirow{2}{*}{ Variables } & $\begin{array}{l}\text { Oil Rent } \\
\text { (Mail Model) }\end{array}$ & $\begin{array}{l}\text { Governance } \\
\text { CS-ARDL }\end{array}$ & $\begin{array}{l}\text { Oil Rent and } \\
\text { Governance }\end{array}$ & $\begin{array}{l}\text { Low } \\
\text { Governance } \\
\text { CS-ARDL }\end{array}$ & $\begin{array}{l}\text { High } \\
\text { Covernance }\end{array}$ \\
\hline \multirow{3}{*}{ FCF } & Long run & Long run & Long run & Long run & Long run \\
& $0.114^{* * * *}$ & $0.068^{* * *}$ & $0.032^{* * *}$ & $0.032^{* * * *}$ & $0.061^{* * *}$ \\
GOV & $(0.038)$ & $(0.015)$ & $(0.005)$ & $(0.006)$ & $(0.019)$ \\
& $-0.070^{* * *}$ & $-0.117^{* * *}$ & $-0.026^{* * * *}$ & 0.020 & $-0.144^{* * *}$ \\
PG & $(0.032)$ & $(0.027)$ & $(0.006)$ & $(0.013)$ & $(0.049)$ \\
& $-2.318^{* * * *}$ & $-1.169^{* * *}$ & $-0.700^{* * * *}$ & $-1.203^{* * *}$ & $-0.966^{* * *}$ \\
OILRENT & $(0.843)$ & $(0.189)$ & $(0.093)$ & $(0.150)$ & $(0.227)$ \\
& $0.161^{* * * *}$ & & $0.050^{* * *}$ & $0.036^{* * *}$ & $0.182^{* * * *}$
\end{tabular}




\begin{tabular}{|c|c|c|c|c|}
\hline$(0.061)$ & & $(0.011)$ & $(0.011)$ & $(0.048)$ \\
\hline QOG & $\begin{array}{l}0.771^{*} \\
(0.420)\end{array}$ & $\begin{array}{l}0.560^{\text {**** }} \\
(0.143)\end{array}$ & & \\
\hline OILRENT*QOG & & $\begin{array}{l}0.024^{*} \\
(0.013)\end{array}$ & & \\
\hline
\end{tabular}

\begin{tabular}{|c|c|c|c|c|c|}
\hline & Short run & Short run & Short run & Short run & Short run \\
\hline Error Correction & $\begin{array}{l}-0.010^{* * *} \\
(0.003)\end{array}$ & $\begin{array}{l}-0.015^{* * *} \\
(0.004)\end{array}$ & $\begin{array}{l}-0.043^{* * *} \\
(0.010)\end{array}$ & $\begin{array}{l}-0.025^{* *} \\
(0.012)\end{array}$ & $\begin{array}{l}-0.016^{* * *} \\
(0.005)\end{array}$ \\
\hline D.FCF & $0.004^{* * *}$ & $0.004^{* * * *}$ & $0.004^{* * *}$ & $0.004^{* * * *}$ & 0.004 \\
\hline D.GOV & $\begin{array}{l}(0.003) \\
-0.006^{* * *} \\
(0.002)\end{array}$ & $\begin{array}{l}(0.001) \\
-0.005^{* * *} \\
(0.002)\end{array}$ & $\begin{array}{l}(0.001) \\
-0.006^{* * *} \\
(0.001)\end{array}$ & $\begin{array}{l}(0.001) \\
-0.004^{* *} \\
(0.002)\end{array}$ & $\begin{array}{l}(0.002) \\
-0.006^{* * *} \\
(0.002)\end{array}$ \\
\hline D.PG & $\begin{array}{l}0.024 \\
(0.053)\end{array}$ & $\begin{array}{l}0.060 \\
(0.047)\end{array}$ & $\begin{array}{l}0.073 \\
(0.063)\end{array}$ & $\begin{array}{l}0.080 \\
(0.102)\end{array}$ & $\begin{array}{l}-0.004 \\
(0.047)\end{array}$ \\
\hline D.OILRENT & $\begin{array}{l}-0.0001 \\
(0.001)\end{array}$ & & $\begin{array}{l}-0.017 \\
(0.011)\end{array}$ & $\begin{array}{l}0.002 \\
(0.002)\end{array}$ & $\begin{array}{l}0.0001 \\
(0.003)\end{array}$ \\
\hline D.QOG & & $\begin{array}{l}0.050 \\
(0.077)\end{array}$ & $\begin{array}{l}0.167 \\
(0.172)\end{array}$ & & \\
\hline D.OILRENT*QOG & & & $\begin{array}{l}0.012 \\
(0.017)\end{array}$ & & \\
\hline Constant & $\begin{array}{l}-0.150^{* * * *} \\
(0.048)\end{array}$ & $\begin{array}{l}0.171^{* * * *} \\
(0.038)\end{array}$ & $\begin{array}{l}0.063 \\
(0.359)\end{array}$ & $\begin{array}{l}0.210^{*} \\
(0.106)\end{array}$ & $\begin{array}{l}0.200^{* * *} \\
(0.056)\end{array}$ \\
\hline Observations & 1085 & 1085 & 1085 & 560 & 525 \\
\hline Number of groups & 31 & 31 & 31 & 16 & 15 \\
\hline CD Test & 38.01 & 13.48 & 20.62 & 22.12 & 27.72 \\
\hline
\end{tabular}

With regard to the control variable in main model, the long-term coefficient of fixed capital formation was statistically significant at the $1 \%$ level. The estimated coefficient suggested that a one-unit increase in gross fixed capital formation would lead to approximately 0.114 units of increase in economic growth for these countries. The economic reasoning for such a result is appealing. Fixed capital formation does lead to an optimum combination of labour and capital that in turn increases the productivity of labour, as argued in the Cobb-Douglas production function. Our findings coincide with the findings of Arcand et al. (2014); Loayza and Ranciere (2006); Wu et al. (2010) and Samargandi et al. (2015).

In line with our postulation in the introduction section, Table 2 reports the negative and significant role of government expenditure in the long and short terms because high government expenditure is a proxy for less space for the efficient development of the private sector and for a high level of corruption (Goel and Nelson, 1998; Montinola and Jackman, 2002). This condition results in reduced economic outputs (Barro, 1990; Barro, 1999; Loayza and Ranciere, 2006). Furthermore, high government expenditure is a proxy for increased tax burden, which leads to a reduction in private spending and investment. This result indicates that a high population growth is a burden on the economy.

\subsection{GROWTH AND RESOURCE: ROLE OF FINANCIAL DEVELOPMENT}

Our fourth hypothesis is that the impact of oil rent is significant in the presence of high financial development. To examine this hypothesis, we used FD as the regressor in the model and interaction between FD and oil rent. To check robustness, we split the sample into high and low levels of FD. Table 3 shows that the error correction coefficients for all estimated models are negative and statistically significant and there is a long-run relation between economic growth and its predictors. The result indicates that the direct impact of oil rent and FD are insignificant in the long and short term. The coefficient of interaction variable (FD $\times$ Oil Rent) is negative and insignificant, which indicates 
that oil rent and FD jointly play an insignificant role in promoting economic growth. Despite the plausible role of financial development in mobilising the oil rent in the private sector for the overall economy to flourish, our result nullified the hypothesis. The result can be explained by the fact that in the presence of an authoritarian government structure and narrow-base economies, oil rent is confined within the hands of a few. Hence, FD is often unable to mobilise oil rent from the government to the private sector. Likewise, the result shows positive and significant coefficient of oil rent in the long-term economies of low financial developed countries.

Table 3: Growth and resource: role of financial development

\begin{tabular}{|c|c|c|c|}
\hline Variables & $\begin{array}{l}\text { Oil Rent and FD } \\
\text { CS-ARDL }\end{array}$ & $\begin{array}{l}\text { Low Financial } \\
\text { Development } \\
\text { CS-ARDL }\end{array}$ & $\begin{array}{l}\text { High Financial } \\
\text { Development } \\
\text { CS-ARDL }\end{array}$ \\
\hline \multirow{3}{*}{ FCF } & Long run & Long run & Long run \\
\hline & -0.267 & $0.021^{* * * *}$ & 0.022 \\
\hline & $(0.183)$ & $(0.003)$ & $(0.031)$ \\
\hline \multirow[t]{2}{*}{ GOV } & $-0.251^{*}$ & -0.005 & -0.077 \\
\hline & $(0.152)$ & $(0.004)$ & $(0.048)$ \\
\hline \multirow[t]{2}{*}{ PG } & 8.464 & $-0.081^{* * *}$ & $-0.4444^{*}$ \\
\hline & $(5.740)$ & $(0.012)$ & $(0.241)$ \\
\hline \multirow[t]{2}{*}{ OILRENT } & -0.242 & $0.018^{* * *}$ & -0.023 \\
\hline & $(0.171)$ & $(0.003)$ & $(0.026)$ \\
\hline \multirow[t]{2}{*}{ FD } & 0.057 & & \\
\hline & $(0.038)$ & & \\
\hline \multirow[t]{3}{*}{ OILRENT*FD } & -0.005 & & \\
\hline & $(0.004)$ & & \\
\hline & Short run & Short run & Short run \\
\hline \multirow[t]{2}{*}{ Error Correction } & $-0.002^{*}$ & $-0.063^{\text {**** }}$ & $-0.102^{*}$ \\
\hline & $(0.001)$ & $(0.023)$ & $(0.058)$ \\
\hline \multirow[t]{2}{*}{ D.FCF } & $0.005^{* * *}$ & $0.004^{* * *}$ & $0.005^{* * *}$ \\
\hline & $(0.001)$ & $(0.002)$ & $(0.001)$ \\
\hline \multirow[t]{2}{*}{ D.GOV } & $-0.005^{*}$ & -0.001 & $-0.010^{* * * *}$ \\
\hline & $(0.002)$ & $(0.002)$ & $(0.003)$ \\
\hline \multirow[t]{2}{*}{ D.PG } & -0.052 & 0.121 & -0.059 \\
\hline & $(0.065)$ & $(0.001)$ & $(0.044)$ \\
\hline \multirow[t]{2}{*}{ D.OILRENT } & 0.001 & 0.002 & 0.001 \\
\hline & $(0.003)$ & $(0.002)$ & $(0.003)$ \\
\hline \multirow[t]{2}{*}{ D.FD } & 0.002 & & \\
\hline & $(0.002)$ & & \\
\hline \multirow[t]{2}{*}{ D.OILRENT*FD } & -0.0002 & & \\
\hline & $(0.0002)$ & & \\
\hline \multirow[t]{2}{*}{ Constant } & 0.017 & $0.631^{* * *}$ & $1.693^{*}$ \\
\hline & $(0.018)$ & $(0.227)$ & $(0.959)$ \\
\hline Observations & 1085 & 748 & 306 \\
\hline Number of Groups & 31 & 22 & 9 \\
\hline CD Test & 11.24 & 20.56 & 77.98 \\
\hline
\end{tabular}

\subsection{ECONOMIC GROWTH AND RESOURCE: ROLE OF GLOBALISATION}


We also hypothesise in our framework that the role of oil rent is supposed to be significant in countries with high economic globalisation status. Globalisation is an essential process of interconnections and interdependencies among countries, and its main manifold domain includes political, economic and social dimensions. It has been evolving and has been reshaped with the multiple arenas of development, namely, degree of trade openness, marketing activities, business operations, minimising transport and transaction costs and advancement in technological diffusion over time (Frankel and Romer, 1999). Therefore, globalisation is an important channel through which oil rent can boost the economy.

The existence of long-run relation between economic growth and its predictors is confirmed by the negative and significant coefficient of error correction. The second column of Table 4 indicates that the direct impact of globalisation and the coefficient of the joint variable (oil rent $\times$ globalisation) are positive and significant in the long term. To check for robustness, we split the sample into higher and lower globalisation. Table 4 shows that the coefficient of oil rent is positive and significant in the low-globalisation and high-globalisation countries. Our robust analysis indicates that the globalisation process is worthwhile towards economic growth. This finding can be explained by the fact that globalisation necessarily promote economic growth. Wei (2006) documented that globalisation can lead to economic growth only if a threshold level of institutional quality exists, which would lead to a desirable composition of capital inflows for the capital-importing country.

Table 4: Growth and resource: role of globalisation

\begin{tabular}{|c|c|c|c|}
\hline Variables & $\begin{array}{l}\text { Oil Rent and } \\
\text { Globalisation } \\
\text { CS-ARDL }\end{array}$ & $\begin{array}{l}\text { Low Globalisation } \\
\text { CS-ARDL }\end{array}$ & $\begin{array}{l}\text { High Globalisation } \\
\text { CS-ARDL }\end{array}$ \\
\hline \multirow{3}{*}{ FCF } & Long run & Long run & Long run \\
\hline & $0.062^{* * * *}$ & $0.051^{* * *}$ & $0.032^{*}$ \\
\hline & $(0.014)$ & $(0.010)$ & $(0.019)$ \\
\hline \multirow[t]{2}{*}{ GOV } & -0.014 & $-0.078^{* * *}$ & $-0.112^{* * * *}$ \\
\hline & $(0.011)$ & $(0.019)$ & $(0.037)$ \\
\hline \multirow[t]{2}{*}{ PG } & $-0.999^{* * *}$ & $-0.675^{* * *}$ & $-0.409^{* * *}$ \\
\hline & $(0.234)$ & $(0.161)$ & $(0.156)$ \\
\hline \multirow[t]{2}{*}{ OILRENT } & 0.030 & $0.087^{* * * *}$ & $0.128^{* * * *}$ \\
\hline & $(0.023)$ & $(0.020)$ & $(0.044)$ \\
\hline \multirow[t]{2}{*}{ QLO } & $0.025^{* * *}$ & & \\
\hline & $(0.008)$ & & \\
\hline \multirow[t]{3}{*}{ OILRENT* QLO } & $0.001^{* * *}$ & & \\
\hline & $(0.001)$ & & \\
\hline & Short run & Short run & Short run \\
\hline \multirow[t]{2}{*}{ Error Correction } & $-0.021^{* * * *}$ & $-0.031^{* * *}$ & $-0.012^{* *}$ \\
\hline & $(0.005)$ & $(0.007)$ & $(0.005)$ \\
\hline \multirow[t]{2}{*}{ D.FCF } & $0.004^{* * *}$ & 0.002 & $0.007^{* * *}$ \\
\hline & $(0.001)$ & $(0.002)$ & $(0.003)$ \\
\hline \multirow[t]{2}{*}{ D.GOV } & $-0.006^{* * * *}$ & $-0.005^{* *}$ & $-0.005^{* * * *}$ \\
\hline & $(0.002)$ & $(0.003)$ & $(0.002)$ \\
\hline \multirow[t]{2}{*}{ D.PG } & 0.002 & 0.085 & -0.050 \\
\hline & $(0.060)$ & $(0.100)$ & $(0.050)$ \\
\hline \multirow[t]{2}{*}{ D.OILRENT } & 0.002 & $0.004^{* * *}$ & $0.003^{*}$ \\
\hline & $(0.002)$ & $(0.001)$ & $(0.002)$ \\
\hline \multirow[t]{2}{*}{ D.QLO } & -0.001 & & \\
\hline & $(0.002)$ & & \\
\hline \multirow[t]{2}{*}{ D.OILRENT* QLO } & $-0.00003^{* * *}$ & & \\
\hline & $(0.00001)$ & & \\
\hline \multirow[t]{2}{*}{ Constant } & $0.232^{* * *}$ & $0.342^{* * *}$ & $0.180^{* * *}$ \\
\hline & $(0.053)$ & $(0.081)$ & $(0.072)$ \\
\hline
\end{tabular}




\begin{tabular}{llll} 
Observations & 1054 & 630 & 455 \\
Number of Groups & 31 & 18 & 13 \\
CD Test & 31.30 & 61.07 & 26.30 \\
\hline
\end{tabular}

Note: $* * * * *$ and $*$ indicate the level of significance at $1 \%, 5 \%$, and $10 \%$, respectively. The numbers in parentheses show the standard errors.

\subsection{ECONOMIC GROWTH AND RESOURCE: ROLE OF WAR}

The sixth hypothesis of this study is that resource-based economies suffer from or undergo internal and external conflicts due to rebels and greedy outsiders, and these conflicts appear as substantial economic shocks. Such shocks are profound from the macroeconomic perspective because these economies respond highly to resource revenue. Therefore, war is an important contextualisation in the resource-growth linkage. In examining the hypothesis, we considered several war dummy variables, such as Iran-Iraq, Iraq-US, Libya-US and Iraq-Kuwait. We measured the direct impact of war. Table 6 shows that the coefficient of Iraq-US war dummy was negative and significant in the long term. The impact of oil rent was positive and significant in the short and long term. Our findings are in line with those of prior studies, such as Collier and Hoeffler (1998, 2004), Ross (2004), Lujala et al. (2005) and McKillop (2004).

Table 5: Growth and resource: role of war

\begin{tabular}{|c|c|c|c|c|}
\hline Variables & $\begin{array}{l}\text { (Iran-Iraq War) } \\
\text { CS-ARDL }\end{array}$ & $\begin{array}{l}\text { (Iraq-US War) } \\
\text { CS-ARDL }\end{array}$ & $\begin{array}{l}\text { (Libya-US War) } \\
\text { CS-ARDL }\end{array}$ & $\begin{array}{l}\text { (Iraq-Kuwait War) } \\
\text { CS-ARDL }\end{array}$ \\
\hline & Long run & Long run & Long run & Long run \\
\hline $\mathrm{FCF}$ & $0.050^{* * *}$ & $0.097^{* * *}$ & $0.017^{* *}$ & $0.068^{* * *}$ \\
\hline GOV & $\begin{array}{l}-0.037^{* * *} \\
(0.015)\end{array}$ & $-0.212^{* * * *}$ & $-0.166^{* * *}$ & $-0.130^{* * * *}$ \\
\hline PG & $-1.549^{* * *}$ & $-2.892^{* * * *}$ & $0.288^{* * *}$ & $-1.668^{* * * *}$ \\
\hline OILRENT & $\begin{array}{l}(0.258) \\
0.085^{* * * *} \\
(0.020)\end{array}$ & $\begin{array}{l}(0.928) \\
0.203^{* * * *} \\
(0.069)\end{array}$ & $\begin{array}{l}(0.072) \\
-0.061^{* * *} \\
(0.010)\end{array}$ & $\begin{array}{l}(0.335) \\
0.121^{* * * *} \\
(0.029)\end{array}$ \\
\hline Iran-Iraq War Dummy & $\begin{array}{l}-0.039 \\
(0.088)\end{array}$ & & & \\
\hline Iraq-US War Dummy & & $\begin{array}{l}-0.507^{* *} \\
(0.248)\end{array}$ & & \\
\hline Libya-US War Dummy & & & $\begin{array}{l}-0.015 \\
(0.182)\end{array}$ & \\
\hline Iraq-Kuwait War Dummy & & & & $\begin{array}{l}0.191 \\
(0.192)\end{array}$ \\
\hline & Short run & Short run & Short run & Short run \\
\hline Error Correction & $\begin{array}{l}-0.018^{* * *} \\
(0.005)\end{array}$ & $\begin{array}{l}-0.008^{* * *} \\
(0.002)\end{array}$ & $\begin{array}{l}-0.004 \\
(0.007)\end{array}$ & $\begin{array}{l}-0.017^{* * *} \\
(0.003)\end{array}$ \\
\hline D.FCF & $\begin{array}{l}0.004^{* * * *} \\
(0.001)\end{array}$ & $\begin{array}{l}0.004^{* * * *} \\
(0.001)\end{array}$ & $\begin{array}{l}0.005^{* * * *} \\
(0.001)\end{array}$ & $\begin{array}{l}0.004^{* * * *} \\
(0.001)\end{array}$ \\
\hline D.GOV & $\begin{array}{l}-0.005^{* * *} \\
(0.002)\end{array}$ & $\begin{array}{l}-0.006^{* * *} \\
(0.002)\end{array}$ & $\begin{array}{l}-0.005^{* * *} \\
(0.002)\end{array}$ & $\begin{array}{l}-0.005^{* * *} \\
(0.002)\end{array}$ \\
\hline D.PG & $\begin{array}{l}0.002 \\
(0.055)\end{array}$ & $\begin{array}{l}0.020 \\
(0.045)\end{array}$ & $\begin{array}{l}0.053 \\
(0.063)\end{array}$ & $\begin{array}{l}0.019 \\
(0.043)\end{array}$ \\
\hline D.OILRENT & $0.002^{*}$ & $0.002^{*}$ & 0.001 & $0.002^{*}$ \\
\hline
\end{tabular}




\begin{tabular}{|c|c|c|c|c|}
\hline & $(0.001)$ & $(0.001)$ & $(0.001)$ & $(0.001)$ \\
\hline D. Iran-Iraq War Dummy & $\begin{array}{l}-0.003 \\
(0.007)\end{array}$ & & & \\
\hline D. Iraq-US War Dummy & & $\begin{array}{l}0.001 \\
(0.010)\end{array}$ & & \\
\hline D.Libya-US War Dummy & & & $\begin{array}{l}0.001 \\
(0.002)\end{array}$ & \\
\hline D.Iraq-Kuwait War Dummy & & & & $\begin{array}{l}0.001 \\
(0.005)\end{array}$ \\
\hline Constant & $\begin{array}{l}0.180^{* * *} \\
(0.050)\end{array}$ & $\begin{array}{l}0.102^{* * *} \\
(0.030)\end{array}$ & $\begin{array}{l}0.042 \\
(0.077)\end{array}$ & $\begin{array}{l}0.140^{* * *} \\
(0.035)\end{array}$ \\
\hline Observations & 1085 & 1085 & 1085 & 1085 \\
\hline Number of groups & 31 & 31 & 31 & 31 \\
\hline CD Test & 25.20 & 19.02 & 10.41 & 21.21 \\
\hline
\end{tabular}

Note: $* * *, * *$ and $*$ indicate the level of significance at $1 \%, 5 \%$, and $10 \%$, respectively. The numbers in parentheses show the standard errors.

\section{CONCLUSION}

This study obtained several interesting results by scrutinising the resource-economic growth nexus and considering several channels in the context of 31 oil-rich countries. By applying advanced panel-time series techniques, crosssectionally augmented distributed lag (CS-ARDL) approach, cross-sectional dependence and heterogeneous problems have been solved. This study found that oil rent augments economic growth and is thus a blessing rather than a curse. The role of governance effectively explains economic growth in the selected countries. An interesting finding is that oil rent plays a positive and significant role in economic growth in low-governance and highgovernance countries. Financial development is not an important channel in the resource-growth nexus. Surprising, this study revealed that globalisation is worthwhile in the resource-growth nexus. Moreover, war exerts a negative and significant impact on growth only in the long term. This article concludes that resources can be a curse or a blessing depending on governance, financial development, globalisation and war experience.

\section{REFERENCES}

1. Acemoglu, D., \& Robinson, J. A. (2008). The Role of Institutions in Growth and Development. The International Bank for Reconstruction and Development/ The World Bank Working Paper No. 10.

2. Acemoglu, D., \& Robinson J. A. (2012). Why Nations Fail: The Origins of Power, Prosperity, and Poverty. New York: Crown Business.

3. Acemoglu, D., Johnson, S., \& Robinson, J. A. (2001). The Colonial Origins of Comparative Development. American Economic Review, 91(5), 1369-1401.

4. Acemoglu, D., Johnson, S., \& Robinson, J. A. (2005). The rise of Europe: Atlantic trade, institutional change, and economic growth. The American Economic Review, 95(3), 546-579.

5. Alcalá, F., \& Ciccone, A. (2004). Trade and productivity. The Quarterly journal of economics, 119(2), 613-646.

6. Alexeev, M., \& Conrad, R. (2009). The elusive curse of oil. The Review of Economics and Statistics, 91(3), 586598.

7. Al-Mamun, M., Sohag, K., \& Hassan, M. K. (2017). Governance, resources and growth. Economic Modelling 63: 238-261.

8. Al-Marhubi, F. (2004). The Determinants of Governance: A Cross-Country Analysis. Contemporary Economic Policy, 22, 394-406.

9. Ang, J. (2008). What are the mechanisms linking financial development and economic growth in Malaysia?. Economic Modelling, 25, 38-53. 
10.Apergis, N., \& Payne, J. E. (2014). Renewable energy, output, $\mathrm{CO}_{2}$ emissions, and fossil fuel prices in Central America: evidence from a nonlinear panel smooth transition vector error correction model. Energy Economics, 42, 226-232.

11.Arcand, J. L., Berkes, E., \& Panizza, U. (2014). Finance and economic development in a model with credit rationing. In The Social Value of the Financial Sector: Too Big to Fail or Just Too Big? World Scientific, 67-80.

12.Arezki, R., \& Van der Ploeg, R. (2007). Can the natural resource curse be turned into a blessing? The role of trade policies and institutions. IMF Working Papers, 1-34.

13.Auty, R. M. (1990). Resource-based industrialization: sowing the oil in eight developing countries. Business \& Economics, Oxford University Press, New York.

14.Auty, R. M. (1994). The resource curse thesis: Minerals in Bolivian development, 1970-90. Singapore Journal of Tropical Geography, 15(2), 95-111.

15.Barro, R. J. (1990). Government spending in a simple model of endogeneous growth. Journal of political economy, 98(5, Part 2), 103-125.

16.Barro, R. J. (1999). Determinants of democracy. Journal of Political economy, 107(S6), 158-183.

17.Beck, T. (2009). The Econometrics of Finance and Growth. Handbook of Econometrics, eds. T. Mills \& K. Patterson. Chapter 2. Palgrave Macmillan.

18.Beck, T., Levine, R., \& Loayza, N. (2000). Finance and the sources of growth. Journal of Financial Economics, 58, 261-300.

19.Bhattacharyya, S., \& Hodler, R. (2010). Natural resources, democracy and corruption. European Economic Review, 54, 608-621.

20.Bhattacharyya, S., \& Hodler, R. (2014). Do natural resource revenues hinder financial development? The role of political institutions. World Development, 57, 101-113.

21.Blackburn, K., \& Forgues-Puccio, G. F. (2009). Why is corruption less harmful in some countries than in others?. Journal of Economic Behavior \& Organization, 72(3), 797-810.

22.Bond, S., \& Eberhardt, M. (2013). Accounting for unobserved heterogeneity in panel time series models. Nuffield College, University of Oxford, mimeo.

23.Brunnschweiler, C .N. (2008). Cursing the blessings? Natural resource abundance, institutions, and economic growth. World development, 36(3), 399-419.

24.Butkiewicz, J. L., \& Yanikkaya, H. (2006). Institutional quality and economic growth: Maintenance of the rule of law or democratic institutions, or both. Economic Modelling, 23, 648-661.

25.Calderón, C., \& Liu, L. (2003). The direction of causality between financial development and economic growth. Journal of Development Economics, 72(1), 321-334.

26.Cass, D. (1965). Optimum growth in an aggregative model of capital accumulation. The Review of Economic Studies, 32(3), 233-240.

27.Cavalcanti, T. V. D. V., Mohaddes, K., \& Raissi, M. (2011a). Growth, development and natural resources: New evidence using a heterogeneous panel analysis. The Quarterly Review of Economics and Finance, 51(4), 305-318.

28.Cavalcanti, T. V. D. V., Mohaddes, K., \& Raissi, M. (2011b). Does oil abundance harm growth?. Applied Economics Letters, 18(12), 1181-1184.

29.Charron, N., Lapuente, V., \& Rothstein, B. (2010). Measuring the Quality of Government and Subnational Variation. Report for the European Commission Directorate-General Regional Policy Directorate Policy Development. Brussels: European Union.

30.Chudik, A., \& Pesaran, M. H. (2015). Large panel data models with cross-sectional dependence: A survey. In The Oxford Handbook of Panel Data, ed. B. H. Baltagi, chap. 1, 2-45. Oxford: Oxford University Press.

31.Collier, P., \& Hoeffler, A. (1998). On economic causes of civil war. Oxford economic papers, 50(4), 563-573.

32.Collier, P., \& Hoeffler, A. (2004). Greed and grievance in civil war. Oxford Economic Papers, 56, 563-595.

33.Deidda, L. (2006). Interaction between economic and financial development. Journal of Monetary Economics, $53,233-248$.

34.Demetriades, P., \& Hook Law, S. (2006). Finance, institutions and economic development. International journal of finance \& economics, 11(3), 245-260.

35.Dollar, D., \& Kraay, A. (2002). Growth is good for the poor. Journal of Economic Growth, 7, 195-225. 
36.Ebeke, C., Omgba, L. D., \& Laajaj, R. (2015). Oil, governance and the (mis) allocation of talent in developing countries. Journal of Development Economics, 114, 126-141.

37.Fowowe, B. (2010). The finance-growth nexus in Sub-Saharan Africa: panel cointegration and causality tests. Journal of International Development, 23, 220-239.

38.Frankel, J. A. \& Romer, D. (1999). Does trade cause growth?. American economic review, 89(3), 379-399.

39.Gelb, A. H. (1988). Windfall Gains: Blessing or Curse?. New York: Oxford University Press.

40.Goel, R. K., \& Nelson, M. A. (1998). Corruption and government size: A disaggregated analysis. Public Choice, 97(1-2), 107-120.

41.Goodhart, C. A. E. (2004). Some new directions for financial stability? (Vol. 27). Bank for International Settlements.

42.Gylfason, T. (2001). Natural resources, education, and economic development. European Economic Review, 45(4), 847-859.

43.Hsiao, C. (2003). Analysis of panel data. Cambridge: Cambridge university press.

44.James, A. (2015). The resource curse: a statistical mirage?. Journal of Development Economics, 114, 55-63.

45.Kim, D. H., \& Lin, S. C. (2015). Natural resources and economic development: new panel evidence. Environmental and Resource Economics, 66(2), 1-29.

46.Knack, S., \& Keefer, P. (1995). Institutions and economic performance: cross-country tests using alternative institutional measures. Economics \& Politics, 7(3), 207-227.

47.Koopmans, T.C. (1963). On the concept of optimal economic growth. Cowles Foundation Discussion Papers 163, Cowles Foundation for Research in Economics, Yale University.

48.Le Billon, P. (2001). The political ecology of war: natural resources and armed conflicts. Political geography 20(5), 561-584.

49.Loayza, N. V., \& Ranciere, R. (2006). Financial development, financial fragility, and growth. Journal of Money, Credit and Banking, 1051-1076.

50.Lucas, R.E. (1988). On the mechanics of economic development. Journal of monetary economics 22(1): 3-42.

51.Lujala, P., Gleditsch, N. P., \& Gilmore, E. (2005). A diamond curse? Civil war and a lootable resource. Journal of Conflict Resolution, 49(4), 538-562.

52.McKillop, A. (2004). Oil price trends through 2004-2010. Petroleum World.

53.Mehlum, H., Moene, K., \& Torvik, R. (2006). Institutions and the Resource Curse. The Economic Journal, 116(508), 1-20.

54. Montinola, G. R., \& Jackman, R. W. (2002). Sources of corruption: A cross-country study. British Journal of Political Science, 32(1), 147-170.

55.North, D. (1990). Institutions, Institutional Change, and Economic Performance. Cambridge, Cambridge University Press.

56.North, D. C., \& Thomas, R. P. (1973). The rise of the western world: A new economic history. Cambridge University Press.

57.Pedroni, P. (2000). Fully Modified OLS for Heterogeneous Cointegrated Panels. Advances in Econometrics, 15, 93-130.

58.Pedroni, P. (2001). Purchasing Power Parity Tests in Cointegrated Panels. The Review of Economics and Statistics, 83(4), 727-731.

59.Pesaran, M. H. (2004). General diagnostic tests for cross section dependence in panels. CESifo Working Paper Series No. 1229.

60.Pesaran, M. H. (2006). Estimation and inference in large heterogeneous panels with a multifactor error structure. Econometrica, 74, 967-1012.

61.Pesaran, M. H. (2007). A simple panel unit root test in the presence of cross-section dependence. Journal of Applied Econometrics, 22(2), 265-312.

62.Pesaran, M. H., Shin, Y., \& Smith, R. P. (1999). Pooled mean group estimation of dynamic heterogeneous panels. Journal of the American Statistical Association, 94(446), 621-634.

63.Pesaran, M. H., \& Smith, R. (1995). Estimating long-run relationships from dynamic heterogenous panels. Journal of Econometrics, 68, 79-113. 
64.Pesaran, M. H., \& Tosetti, E. (2011). Large panels with common factors and spatial correlation. Journal of Econometrics, 161(2), 182-202.

65.Raz, A. (2013). The nexus between bank credit development and economic growth in Indonesia. DLSU Business \& Economics Review, 23, 93-104.

66.Rigobon, R., \& Rodrik, D. (2005). Rule of law, democracy, openness and income: estimating the interrelationships. Economics of Transition, 13(3), 533-564.

67.Romer, P. M. (1986). Increasing returns and long-run growth. The Journal of Political Economy, 94(5), 10021037.

68.Ross, M. L. (2001). Does oil hinder democracy?. World politics, 53(3), 325-361.

69. Ross, M. L. (2004). What do we know about natural resources and civil war?. Journal of peace research, 41(3), 337-356.

70.Rufael, Y. (2009). Re-examining the financial development and economic growth nexus in Kenya. Economic Modelling, 26, 1140-1146.

71.Sachs, J. D., \& Warner, A. M. (1995). Natural resource abundance and economic growth. National Bureau of Economic Research Working Paper No. 5398.

72.Sachs, J. D., \& Warner, A. M. (1999). The big push, natural resource booms and growth. Journal of Development Economics, 59(1), 43-76.

73.Sachs, J. D., \& Warner, A. M. (2001). The curse of natural resources. European Economic Review, 45(4), 827838.

74.Samargandi, N., Fidrmuc, J., \& Ghosh, S. (2015). Is the relationship between financial development and economic growth monotonic? Evidence from a sample of middle-income countries. World Development, 68, 66-81.

75.Smith, B. (2015). The resource curse exorcised: Evidence from a panel of countries. Journal of Development Economics, 116, 57-73.

76. Solow, R. M. (1956). A contribution to the theory of economic growth. The Quarterly Journal of Economics 70(1), 65-94.

77.Van Der Ploeg, F. \& Poelhekke, S. (2010). The Pungent Smell of "Red Herrings": Subsoil assets, rents, volatility and the resource curse. Journal of Environmental Economics and Management, 60(1), 44-55.

78.Van der Ploeg, F. (2011). Natural Resources: Curse or Blessing?. Journal of Economic Literature, 49(2), 366420.

79.Wei, S. J. (2006). Connecting two views on financial globalization: Can we make further progress?. Journal of the Japanese and International Economies, 20(4), 459-481.

80.Wu, S-Y., Tang, J-H., \& Lin, E. S. (2010). The impact of government expenditure on economic growth: How sensitive to the level of development?. Journal of Policy Modeling, 32(6), 804-817.

81.Wurgler, J. (2000). Financial Markets and the Allocation of Capital. Journal of Financial Economics, 58, 187214.

82. Yang, Y., \& Yi, M. (2008). Does financial development cause economic growth? Implication for policy in Korea. Journal of Policy Modeling, 30, 827-840.

83.Zhang, J., Wang, L., \& Wang, S. (2012). Financial development and economic growth: recent evidence from China. Journal of Comparative Economics, 40, 393-412. 